\title{
INSTITUTIONAL COOPERATION ON MIGRATION AND ASYLUM IN THE EU AND IN SLOVAKIA IN CONNECTION WITH ITS ACCESSION TO THE EU
}

\author{
Stanislav Filip \\ School of Economics and Management in Public Administration, Bratislava, Slovakia \\ Peter Machovič \\ Department of Theory of Law and Social Science, Commenius university in Bratislava, \\ Bratislava, Slovakia
}

\section{Vojtech Kollár}

School of Economics and Management in Public Administration, Bratislava, Slovakia

\section{(C) MESTE NGO}

JEL category: F52

\begin{abstract}
Paper deals with current issues related to migration and integration of foreigners in the changes of globalization. It presents approaches to migration and asylum within the international community and European integration, and the resulting consequences for the Slovak Republic. First part deals with basic requirements that aliens should meet when entering the Schengen area, adopted legislation which covers aliens' stay permit and overview of lodged requests for international protection in Slovak Republic. The second part shows the evolution of the right to asylum from historical concept to the modern way of protection in international law on basis of international conventions within the United Nations and regional development in the European Union. Third part shows the evolution of asylum policy within European Union, its institutional background and introduces the Common European Asylum System. In transparent manner characterizes major legal standards of European Union law that regulate the residence of aliens and asylum issues.
\end{abstract}

Keywords: migration, asylum, integration, residence of aliens, EU law

\section{INTRODUCTION}

Time of globalization has brought a distinctive interdependence of States in various bonds and at different levels. Next to States there are powerful

Address of the corresponding author:

Stanislav Filip

麦=" stanislav.filip@vsemvs.sk multinational corporations at the global scene, economic and trade relations are changing. China has become the largest productive economy in the world. Globally the new engine of the global economy became countries of Asia. The economic crisis of 2008 caused by growth in financial economy has shown the dangers that we can still expect. In a globalized world, there is a 
shift that we cannot influence. Economic crisis in the past were replaced by a period of economic growth and prosperity. But this time the economy is stagnating. A new world for me is an awareness that things have definitely changed and it will be harder for everyone. We have therefore social changes, globalization, new technologies, economic problems and the fact that it all stays with us. Technological and structural changes that we are currently experiencing, reveal completely new horizons, what we have dreamed of (Bukerová, 2013), suggests Janice Caplan, known British consultant in management and organization changes. Changes, however, can be turned to opportunity by company, that is equipped technologically and with human capital enough to adapt flexibly to changing conditions.

\section{RISKS ASSOCIATED WITH MIGRATION IN ECONOMICALLY DEVELOPED COUNTRIES}

One of the most dramatic manifestations of international relations is a growth in a huge differentiation between developed, highly industrialized countries - the world centre and the poor developing countries (Lid'ak, 2009). Number of international migrants has more than doubled in the last 25 years, and another 25 million were added in the first five years of the 21st Century (Koser, 2007). Stating this numbers Koser didn't specify numbers of irregular migrants. Only in Europe lived 6-8 million illegal migrants in 2008 (Zoubek, 2008). By definition of the UN, the migrant is a person who has more than a year lived outside his usual country of residence.

The political and media debates present irregular migration often associated with the notion of state sovereignty threats. To put it simply, the states have the sovereign right to control who crosses their borders, and by the weakening of border control, irregular migrants will threaten sovereignty. The conclusion is that stopping irregular migration is a prerequisite for confirmation of full sovereignty (Koser, 2007). Koser used instead of the term illegal migration, irregular migration, arguing that the human being as such cannot be illegal. The term illegal evokes a connection to committing crimes. Most illegal migrants, although they have violated some laws, according to him, cannot automatically be considered criminals.

Migration should be seen as a complex issue that affects the economic and social context. Model, that foreigners take our jobs is logical at first sight, and one of the frequently used arguments in political debates. But this is a simplification of the issue. Growth of unemployment even in developed Western countries is related to the globalization of the world economy, inter alia, to the above mentioned shift of the production base of the world economy to Asia. On the other hand, it should be noted that migrants often occupy positions known as 3D (dangerous, difficult and dirty) (Koser, 2007).

It is clear, that each state can accept only a certain number of immigrants, without threatening its security and cultural integrity. Of course, there is the risk of enclaves' origin, that are not integrated, that may affect the fragmentation of society subsequently. This problem we have also in Slovakia, where the members of the Roma community are allocated in certain areas. Similarly, the feeling of exclusion, felt by French citizens of Arab origin who do not have access to good education and thus to better paid employment, resulted in riots in 2005. Recent unrest among immigrants in Sweden in May 2013 set the mirror to outwards multicultural looking society. Swedes have given asylum or residence permit for citizens of third countries, but the subsequent integration of these people into society, especially in educational and work process, was not successful. The reason is simple, distrust and unwillingness of the major society to accept these migrants (Slovensky rozhlas 1, 2013).

But to not show to others, we have the same problem with the Roma population in Slovakia as well. Considering text above, it can be concluded that the issues of migration and integration needs to be addressed comprehensively and at the various social platforms as well. But as it is usual, simple explanations appeal to people more and even Angela Merkel in the debate on integration has expressed that putting effort to multiculturalism has failed in Germany. Right away came the answer from opposition claiming it was black and white thinking on immigration. There is need to upgrade skills of long-term 
unemployed and to be open to the immigration of highly skilled workers (Spiegel, 2013). The Netherlands, traditionally considered as immigrant country, adopted in 2012 new legislation. The repeated unfounded asylum application will be considered a criminal offense. The applicant shall be imprisoned for four years or will have to pay a financial penalty 5000 EUR (News RTVS, 2012).

Movement of foreigners and entry to the EU countries is regulated by the Schengen law. To the Schengen Area belongs Austria, Belgium, Czech Republic, Denmark, Estonia, Finland, France, Greece, Iceland, Latvia, Lithuania, Luxembourg, Hungary, Malta, Germany, Norway, Poland, Portugal, Slovakia, Slovenia, Spain, Switzerland, Sweden.

In Schengen is applied free movement of persons, goods, services and capital. This means that the basic conditions of entry into the Schengen Area, so-called short-term visas, are subject to the competence of the EU. If you are not a citizen of the Slovak Republic, you need to enter in Slovakia a Schengen visa. Issuing of these visas is governed by Council Regulation (EC) No. 810/2009. Uniform Schengen visa allows the holder to enter the territory of each Schengen Member State for purpose of visiting friends and relatives, tourism etc. Visas may be issued for a single entry or multiple entries. Length of the alien's stay in the Schengen area must not exceed 90 days in six months from the date of first entry into the Schengen area, while the visa is not for employment, business or a similar gainful activity. There are three kinds of visa, long-term, if intended stay in a Member State is for more than three months, or short length, when stay does not exceed three months, and transit.

Third-country national may reside in Slovakia:

- with granted valid visa or under a visa free travel or with valid residence permit issued by another EU Member State,

- with granted temporary residence,

- with granted permanent residence,

- with granted tolerated stay.

The Application for long-stay visa or for some kind of residence should be lodged in Slovak territory according to relevant provisions of the Act no. 404/2011 Coll. on Residence of Aliens and on amending and supplementing some laws from the 21 October 2011 (further "the Act on Residence of Aliens"). The Act on Residence of Aliens sets out the conditions of aliens' entry into the territory of the Slovak Republic, their return to their country of origin through deportation, provides assisted voluntary returns and has control and sanction mechanisms to prevent illegal conduct and violations of obligations. Whereas frequent reason for illegal migration is to gain employment in the destination country, for aliens are relevant provisions of laws, enabling them to enter the labour market. In Slovakia, it's the law no. 5/2004 Coll. on employment services and on amending and supplementing certain acts, which sets out the obligations of public authorities to detect illegal work and illegal employment. General prohibition of illegal labour is determined by Law no. 82/2005 Coll. of undeclared work and illegal employment and on amendments to certain laws. Penalties for illegal employment are regulated by law no.125/2006 Coll. Labour Inspection Act and on amendments to certain laws.

Although asylum law is only one part of the overall migration policy that deals with granting of other kinds of residence permits, many illegal migrants pass just over the asylum procedure, which is the last chance for them to legalize their stay. EU asylum policy is in this regard really generous. Once a person has applied for asylum, he enters into asylum procedure and the reasons for the request must be evaluated under the law. During this time the states provide food and accommodation. Aliens also have the right to basic health care, in Slovakia provided under the Law no. 576/2004 Coll. of health care and on health care services and on supplying and amending some laws.

On purpose are submitting an application for asylum in particular foreigners, who failed to get another form of residence permit and try thus to avoid deportation from the country. Asylum system is being abused by migrant smugglers, who know that when they leave people in any EU country, there will be taken care of them in a way.

A-Applicants, GA- granted asylum, NGA-not granting asylum, SP-granted subsidiary protection, NGSP-not granting subsidiary protection, Ceased asylum procedure. 
Reading Graphs 1 and 2 we see decrease in number of requests for international protection in SR from year 2007. This is due, first, to relatively high rate of negative decisions in the field of subsidiary protection, second, migrants tend to prefer western Europe countries because there are communities of their people, from that they can get support, not mentioning better economic opportunities.

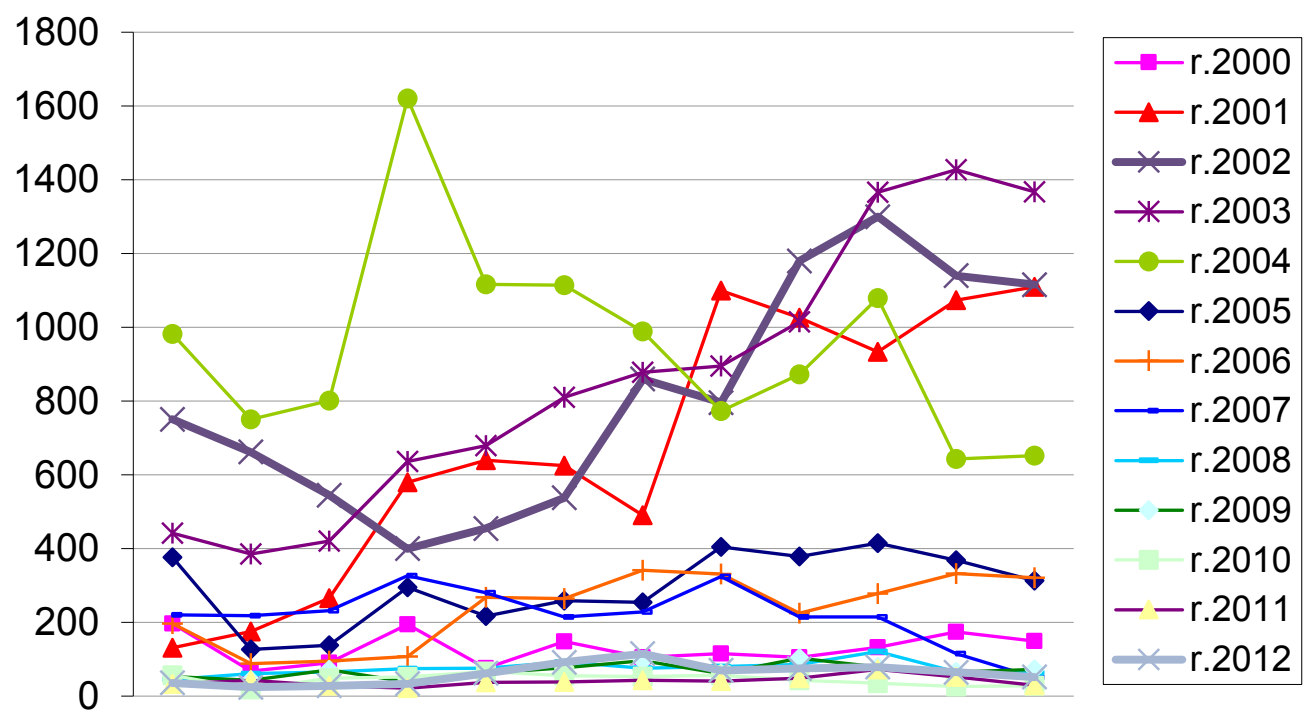

Graph 1 Seekers for International protection in SR 2000-2012

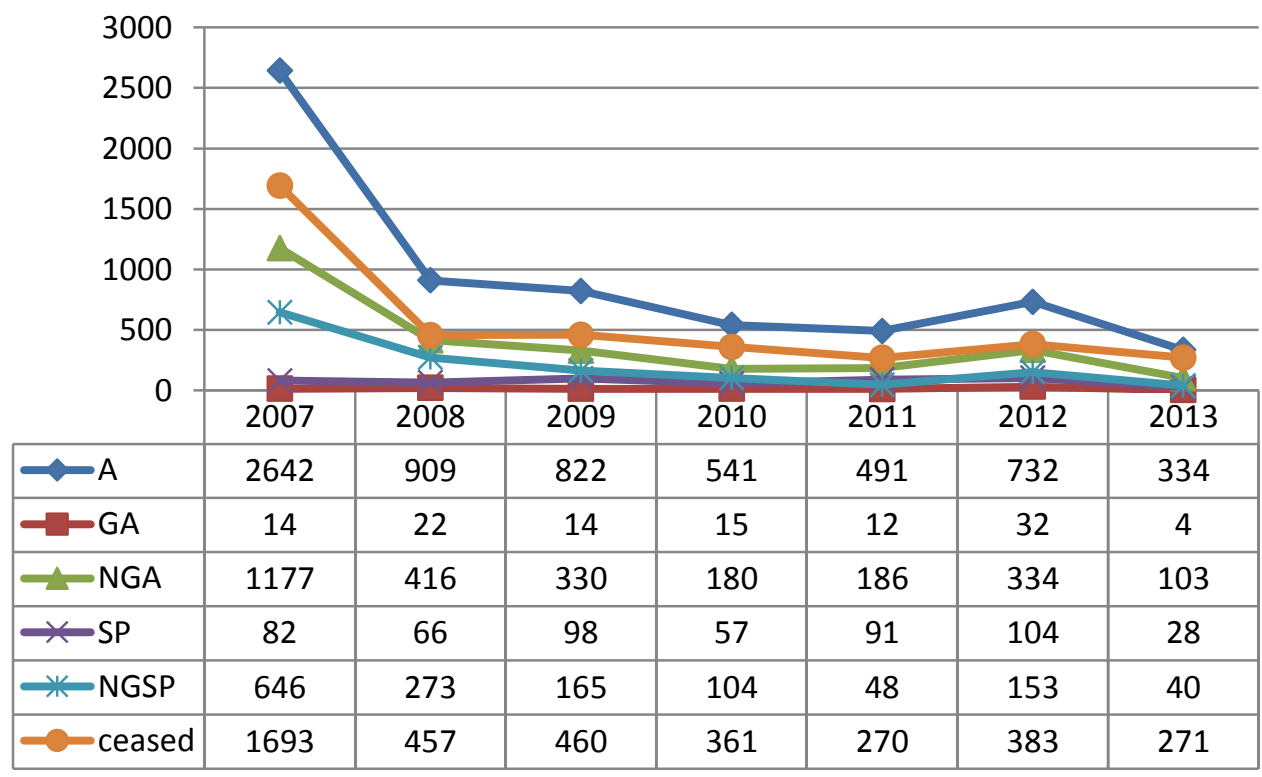

Graph 2 Seekers for International protection in Slovakia 2007-2013

On the one hand, the EU fights against illegal migration, on the other hand its generously conceived asylum system encourages illegal migration. Therefore votes calling for revision of generous asylum system are on the rise. In Slovakia are the questions of international protection provided by the Law no. 480/2002 Coll. on Asylum and on amending certain acts in accordance with the international commitments of the Slovak Republic, the Slovak Constitution and EU legislation on asylum. Let us ask therefore, what the right on asylum is and how it is applied. 


\section{LEGAL ASPECTS ON ASYLUM POLICY}

The right of asylum or right to asylum is an ancient legal concept. From originally religious asylum, which in the Middle Ages provided by the Church to offender of ordinary crimes that - saved from worldly persecution - offenders underwent penance, developed political asylum in 16 Century, when Europe's religiously motivated wars of the Reformation period created necessary social conditions for its stability. Just because of this institute were many believers of both irreconcilable sides protected from mass massacre (David, Sladky, \& Zboril, 2005). As the monarch decided in the past to provide to an alien refuge (asylum), it was a manifestation of sovereignty and he always considered the political consequences of such an act. However, often there were grounds for denial of asylum in general, political asylum as well. Britain's refusal of Napoleon's demand to expel his political opponents from the country, and failed claim of Austria and Russia on the extradition of five thousand political refugees addressed 1849 to Turkey (supported by England), finally stabilized asylum to protection of political offenders (David, Sladky, \& Zboril, 2005).

The Oxford Dictionary of Law under asylum understands refuge granted to an individual whose extradition is sought by a foreign government or who is fleeing persecution in his native state. It is either given refuge in the territory of a foreign country (territorial asylum) or a foreign embassy (diplomatic asylum). The latter is quite contentious, as it is a derogation from the sovereignty of the territorial state (Law \& Martin, 2009).

First, the right to asylum appeared in international public law in Art. 14 of the Universal Declaration of Human Rights adopted in 1948, according to which "everyone has the right to seek and enjoy in other countries asylum from persecution." This right does not apply in case of prosecutions brought against person under serious non-political crimes or on the basis that offences are contrary to the purposes and principles of the United Nations. Right of territorial asylum was further introduced in UN General Assembly Resolution from 1967 (DOCUMENTS A/RES/2312/XXII).
According to this declaration, the right of asylum cannot invoke a person who is reasonably suspected of having committed a crime against peace, a war crime or crime against humanity (Article 1). States that granted asylum may not afford refugee to do an activity that is contrary to the purposes and principles of the United Nations (Article 4) (David, Sladky, \& Zboril, 2005). United Nations Conference on Territorial Asylum was held in Geneva from January $10^{\text {th }}$ to February $4^{\text {th }} 1977$. The States had been able to agree on the wording of five articles of the Convention regarding non-refoulement of asylum seekers and their basic obligations in the country of asylum, however reluctant to adopt the final approval of the text of the Convention. States thus confirmed its unwillingness to restrict the freedom in granting territorial asylum and confirmed the aspiration to keep this affair under its national law, policy and practice (Jankuv, 2006). Up to date there was not adopted an international convention that would institute territorial asylum enshrined in international law. This role largely substitutes Geneva Convention relating to the Status of Refugees adopted by the UN in 1951, as modified by the Protocol of 1967 (Šturma, 2003).

As regional specificity should be noted that the Organization of American States, which was founded in 1948, had adopted in 1954 the Convention on Diplomatic Asylum and the Convention on Territorial Asylum. The contractual arrangements concerns the asylum and granting asylum mainly for political reasons and forms the basis of refugee law in South America (Jankuv, 2006). We also should mention the Cartagena Declaration, which is the result of the conference of government representatives and major Latin American lawyers held in 1984 at Cartagena, Colombia. The Declaration recommends that the refugee definition used in this area includes the definition contained in the Geneva Convention of 1951 and covers also the people who have fled their country because their lives, safety or freedom have been threatened by generalized violence, foreign aggression, internal conflicts, massive violation of human rights or other circumstances which have seriously disturbed public order (UNHCR, 2011). Although the Declaration is not legally binding, most Latin American countries apply this definition in practice. 
In the international context is the corner stone of refugee law the Geneva Convention relating to the Status of Refugees of 1951 (hereinafter "the Convention") modified by New York Protocol of 28 July 1967 (Šturma, 2003). Geneva Convention entered into force on 22 April 1954 and Protocol on 4 October 1967. As a legal category refugees emerged in the early 20th Century. In the period between the world wars considerable number of refugees, 635000 Russian, 55,000 German Jews, 210 Spanish, brought the League of Nations to give them legal status and facilitate their settling in the country of adoption (Berthotyova, 2008).

International meaning of the Geneva Convention and New York Protocol of 1967 from legal point of view is based mainly on the definition of who is and is not a refugee, stipulates the principle of non - refoulement and the creation of the legal status of refugees, their rights and obligations in the country, where them were granted refugee status. These documents contain substantive refugee law, what conditions shall be met to grant refugee status and obligation of States to review the application for refugee status. Procedural rules are adopted under national legislation. This means that each state proceeded on the basis of its national law. Originally Geneva Convention should apply to any who owing to well-founded fear of being persecuted for reasons of race, religion, nationality, membership of a particular social group or political opinion, is outside the country of his nationality and is unable or, owing to such fear, is unwilling to avail himself of the protection of that country; due to events occurring before 1 January 1951 in Europe and elsewhere (UNHCR, 2011). As given by the Article $1 \mathrm{~B}$, for the purposes of this Convention, the words "events occurring before 1 January 1951" in article 1 , section $A$, shall be understood to mean either (a) "events occurring in Europe before 1 January 1951"; or (b) "events occurring in Europe or elsewhere before 1 January 1951"; and each Contracting State shall make a declaration at the time of signature, ratification or accession, specifying which of these meanings it applies for the purpose of its obligations under this Convention. Geographical limitation under Art.1 B (1) a) of the Convention used the Congo, Madagascar, Monaco and Turkey. All other Member States shall recognize the validity of the Convention without any territorial limitation
(UNHCR, States Parties to the Convention 1951 relating to status of refugees and the 1967 Protocol as of 1 April 2011, 2011). Protocol 1967 relating to the Status of Refugees removed the time restriction of the Geneva Convention, which originally applied only to events before 1 January 1951.

Change of social climate in Central and Eastern Europe has caused that Czechoslovakia, which was traditionally a country of emigration, has become a transit country for migrants on their way to Western Europe. Response to this situation was that the Federal Assembly of the Czech and Slovak Federative Republic adopted on 16 November 1990 the Act No. 498/1990 Coll. on refugees. Year later, 26 November 1991, acceded Czech and Slovak Federal Republic to the Geneva Convention and New York Protocol. Documents of the accession of the Czech and Slovak Federative Republic on these treaties were deposited with the Secretary-General of the United Nations, the depositary of the Geneva Convention of 26 November 1991. For the Czech and Slovak Federal Republic Geneva Convention entered into force on 24 February 1992 pursuant to Article 43 paragraph 2 and the New York Protocol in accordance with its Article VIII, paragraph 2 on 26 November 1991.

The right to asylum is included in the catalogue of fundamental rights contained in the Charter of Fundamental Rights and Freedoms, which was put into law through constitutional Act of the Federal Assembly of Czechoslovakia no. 23/1991 Coll. Its adoption was given the right to asylum constitutional framework and later catalogue of fundamental rights of the Charter of Fundamental Rights was incorporated into the second head of the Constitution of SR. Article 53 of the Constitution (alike Article 43 of the Charter of Fundamental Rights and Freedoms) provides that "the Slovak Republic grants asylum to foreigners persecuted for exercising political rights and freedoms. Asylum may be denied to those who acted in violation of fundamental human rights and freedoms. The law sets details."

The existence of territorial asylum in Public International Law we can derive from the customary international law, from the Art. 4 of the Universal Declaration of Human Rights, the text of legally not-binding UN Declaration on Territorial 
Asylum of 1967 and not ratified text of the UN Convention on Territorial Asylum of 1977. The right to grant asylum is unquestionable states' privilege which is of international- legal point of view accepted. The Institute of asylum provides stronger legal regime than refugee status - to asylum beneficiaries are generally applied national legal regime, unlike to refugees who are granted rights of aliens under different regimes. Just because a stronger legal title of asylum European countries mostly included refugee issues under its asylum law (David, Sladky, \& Zboril, 2005).

This approach applied the Council of Europe and later EU, when covering refugee topic with asylum law, causing merging of the right to asylum and refugee law in the EU. This is also clear from the text of the Convention determining the State responsible for examining an asylum application lodged in one of the Member States of the European Communities (1990), signed in Dublin, Ireland (hereinafter referred to as "the Dublin Convention"). Article $1 \mathrm{~b}$ ) of the Dublin Convention sets that for the purpose of the Convention an asylum application regards a request lodged by an alien in a Contracting State seeking protection under Art 1 of the Geneva Convention as amended by the New York Protocol.

\section{MIGRATION POLICY AND ASYLUM SYSTEM IN THE EU}

First discussions on asylum at the level of the European Communities and in informal way, took place in the context of the Single European Act (1986) and the creation of an area of free movement of persons, goods, services and capital in the Member States of the European Community. Until 1999 contractual or other legislation considering the asylum were not part of Community law, which is based on the principle of primacy and on the axiom of its direct application in the Member States. Until 1 November 1993, when entered into force EU Treaty (1992), existed in this area binding conventions having nature of conventions of international public law, as well as several non-binding resolutions and decisions of the Ministers of Interior of EC (Jankuv, 2006). That was the case abovementioned Dublin Convention. EU Treaty of 1992 incorporated the issue of asylum in the EU third pillar, under cooperation in the field of justice and home affairs. The Amsterdam Treaty, which entered into force in 1998, included the Asylum to the first pillar of the EU. This indicated the preparation of common regulation of the asylum systems in the EU countries at the level of Community law. Working on establishing a Common European Asylum System (CEAS) started immediately after Amsterdam Treaty's entering into force in May 1999, based on the guidelines adopted by the European Council meeting in Tampere on 15th16th October 1999. The program focused on coordination of migration policies in the EU countries as well. Aim during the first phase of the CEAS (1999-2005) was to harmonize Member States' legal frameworks on the basis of common minimum standards. This regarded the four basic directive: No. 2001/55/EC on minimum standards for giving temporary protection in the event of a mass influx of displaced persons and on measures promoting a balance of efforts between Member States in receiving such persons and bearing the consequences thereof, No. 2003/9/EC laying down minimum standards for the reception of asylum seekers, No. 2004/83/EC on minimum standards for the qualification and status of third country nationals or stateless persons as refugees or as persons who otherwise need international protection and the content of the protection granted so called Qualification Directive, No. 2005/85/EC on minimum standards on procedures in Member States for granting and withdrawing refugee status so called Procedural Directive.

Furthermore, it was the adoption of the Dublin Regulation (No. 2003/343/EC), including its implementing Regulation (No 2003/1560/EC). The Dublin Regulation is known in Union texts as Dublin II. The objectives of the Tampere were replaced and developed by the Hague Programme of 2004. The goals of the second phase of the CEAS, set out in the Hague Programme, comprised the establishment of a common asylum procedure and a uniform status for those whom have been granted asylum or subsidiary protection, as well as strengthening practical cooperation between national asylum authorities. Now is in force Stockholm Programme of December 2009, which builds on previous programs and provides a framework and sets principles for on-going development of European 
policies on justice and home affairs for the period 2010 to 2014. In the year 2013 were adopted following legal acts of EU in the field of asylum that replace abovementioned standards:

- Directive 2013/32/EU of the European Parliament and of the Council of 26 June 2013 on common procedures for granting and withdrawing international protection,

- Directive 2013/33/EU of the European Parliament and of the Council of 26 June 2013 laying down standards for the reception of applicants for international protection

- Regulation (EU) No 604/2013 of the European Parliament and of the Council of 26 June 2013 establishing the criteria and mechanisms for determining the Member State responsible for examining an application for international protection lodged in one of the Member States by a third-country national or a stateless person,

- Regulation (EU) No 603/2013 of the European Parliament and of the Council of 26 June 2013 on the establishment of "Eurodac" for the comparison of fingerprints for the effective application of Regulation (EU) No. 604/2013

Common legislation should be sustained by the common country of origin information, which will be provided by the European Asylum Support Office, established in 2010.

Illegal migration is along the asylum comprised in Title IV of the Treaty of Lisbon called Area of freedom, security and justice. At The European Commission is for immigration policy responsible Directorate-General for Home Affairs. Some of the most important legal texts adopted in the field of migration and movement of persons include:

- Directive 2003/86/EC on the right to family reunification,

- Directive 2003/109/EC concerning the status of third- country nationals who are long-term residents,

- Directive 2004/38/EC on the right of citizens of the Union and their family members to

- move and reside freely within the territory of the Member States

- Directive 2004/114/EC on the conditions of admission of students ,

- Directive 2005/71/EC relating to facilitating the admission of researchers into the EU ,
- Directive 2008/115/EC concerning the return of third-country nationals who are illegally present in the Member States,

- Directive 2009/50/EC on the admission of highly skilled migrants, so-called blue card directive.

\section{INSTITUTIONAL COOPERATION IN MIGRATION AND ASYLUM IN EU}

When it comes to matters of asylum and resettlement, the EU plays an important role within Europe and beyond. Law and EU policies have a significant impact on the creation of mechanisms for the protection of refugees in many other countries. EU institutions such as the European Council, European Commission, European Parliament and European Court of Justice have legislative, executive and judicial powers. The common legislation have been adopted. Despite directives and regulations which seek to harmonize asylum throughout the EU, there are still big differences between Member States in terms of access to protection, opportunities and number of granted asylums, as well as in the reception conditions. New legislation that was introduced in the third part of this article, have to be followed with common approach at nation level. Implementing and enforcing the EU legislation by national authorities remains a major challenge in the future.

EU migration policy is not formed only by laws on entry and stay of foreigners in the territory of the Member States, but it also includes actions to integrate foreigners into society, equal opportunities in the labour market, in housing, education, employment training and in culture as well. It also covers policy of nation states towards national and ethnic minorities. Important role are playing in this regard NGOs, like International Organisation for Migration, which plays irreplaceable role by assisted voluntary returns to the country of origin. The European Union continues building single European asylum system and operates on a balanced and comprehensive EU immigration policy, in order to take advantage of opportunities that may bring legal migration to European economy and society. It should take into account the needs of the labour market in the EU countries and minimize brain drain from countries outside the EU 
simultaneously. At the same time it is necessary to establish strong integration policies that guarantee the rights of migrants. Common migration policy must also include effective and sustainable return policy, and must deal with the problems associated with illegal migration and to protect its citizens against international crime in order to live and work in safety.

\section{CONCLUSION}

Migration has contributed significantly to the current form of modern Europe, concerning the society as a whole, it continues to play its role. The phenomenon of migration is primarily associated with the development, on the other hand, it is also a source of worry and fear, especially for citizens of developed countries. Foreign Migration is currently an important feature of globalization and one of the major challenges of the 21st century. People coming from different cultures always affect the host community and vice versa. Interaction is an extremely complex process, reaching in different cases different degrees. A cultural influence is often observable only with the passage of years. Disruption of cultural homogeneity, whatever is meant by it, may not be necessarily a negative process, on the contrary it may mean enrichment (Kabeleova, 2013). It is therefore important to address the issues of migration and integration in the wide societal discussion, considering the benefits and risks and to work on the vision of a sustainable migration policy that will benefit us all.

\section{WORKS CITED}

Berthotyova, E. (2008). Medzinarodny system ludskych prav a utečenecke pravo. V Uplatnovanie prav migrujucich osob, imigrantov a žiadatelov o azyl v Slovenskej republike. Bratislava: Bratislavska vysoka škola prava.

Bukerová, V. (2013). Neplytvajme talentom. Profit(16-17).

David, V., Sladky, P., \& Zboril, F. (2005). Medzinarodni pravo verejne. Praha:: Linde Praha.

Jankuv, J. (2006). Medzinarodne a europske mechanizmy ochrany ludskych prav. Bratislava: luraEdition.

Kabeleova, H. (17. 09 2013). Migrace je taky dobrá. Načteno z Multikultúrne centrum Praha: http://aa.ecn.cz/img_upload/f76c21488a048c95bc-

0a5f12deece153/migrace_je_taky_dobra.pdf

Koser, K. (2007). International migration. New York: Oxford University Press.

Law, J., \& Martin, E. A. (Editoři). (2009). Oxford Dictionary of Law (IX. vyd.). New York: OxfordUniversity Press.

Lid'ak, J. (2009). Medzinarodna migracia ako determinant medzinarodnych vzt'ahov po roku 1990. Vedecký obzor(4).

News RTVS. (14. 02 2012). Slovenský rozhlas 1, broadcasted 18.00 . Bratislava, Slovakia.

Slovensky rozhlas 1. (17. 07 2013). Spravy RTVS at 09.00. Bratislava, Slovakia.

Spiegel. (13. 08 2013). Integration:Merkel erklärt Multikulti für gescheitert. Spiegel Online Politik. Načteno z http://www.spiegel.de/politik/deutschland/integration-merkel-erklaert-multikulti-fuergescheitert-a-723532.html

Šturma, P. (2003). Medzinarodni a evropske mechanizmy v oblasti lidskych prav. Praha: C.H. Beck.

UNHCR. (2011). Article 1 letter A paragraph 2 of 1951 Convention. V Handbook and guidelines on procedures and criteria for determining refugee status under 1951 Convention and the 1967 Protocol relating to status of refugees. Geneva: UNHCR. Získáno 22. 05 2014, z http://www.refworld.org/docid/4f33c8d92.html

UNHCR. (01. 04 2011). States Parties to the Convention 1951 relating to status of refugees and the 1967 Protocol as of 1 April 2011. Získáno 22. 05 2014, z UNHCR: http://www.unhcr.org/3b73b0d63.html 
Zoubek, V. (2008). Niekol'ko poznamok k l'udskopravnej problematike globalnej migracie. V A. Zachova, Uplatnovanie prav migrujucich osob, imigrantov a žiadatelov o azyl v Slovenskej republike. Bratislava: Bratislavská vysoká škola práva.

Received for publication: $\quad 22.01 .2014$

Revision received: $\quad 22.05 .2014$

Accepted for publication: $\quad 23.06 .2014$

How to cite this article?

Style - APA Sixth Edition:

Filip, S., Machovič, P., \& Kollar, V. (2014, 07 15). Institutional cooperation on migration and asylum in the EU and in Slovakia in connection with its accession to the EU. (Z. Čekerevac, Ed.) MEST Journal, 2(2), 51-60. doi:10.12709/mest.02.02.02.06

Style - Chicago Fifteenth Edition:

Filip, Stanislav, Peter Machovič, and Vojtech Kollar. 2014. "Institutional cooperation on migration and asylum in the EU and in Slovakia in connection with its accession to the EU." Edited by Zoran Čekerevac. MEST Journal (MESTE) 2 (2): 51-60. doi:10.12709/mest.02.02.02.06.

Style - GOST Name Sort:

Filip Stanislav, Machovič Peter and Kollar Vojtech Institutional cooperation on migration and asylum in the EU and in Slovakia in connection with its accession to the EU [Journal] // MEST Journal / ed. Čekerevac Zoran. - Belgrade : MESTE, 07 15, 2014. - 2 : Vol. 2. - pp. 51-60.

Style - Harvard Anglia:

Filip, S., Machovič, P. \& Kollar, V., 2014. Institutional cooperation on migration and asylum in the EU and in Slovakia in connection with its accession to the EU. MEST Journal, 15 07, 2(2), pp. 51-60.

Style - ISO 690 Numerical Reference:

Institutional cooperation on migration and asylum in the EU and in Slovakia in connection with its accession to the EU. Filip, Stanislav, Machovič, Peter and Kollar, Vojtech. [ed.] Zoran Čekerevac. 2, Belgrade : MESTE, 07 15, 2014, MEST Journal, Vol. 2, pp. 51-60. 